\author{
Anna GRYGLASZEWSKA \\ Uniwersytet Śląski w Katowicach \\ a.gryglaszewska@gmail.com
}

\title{
BEZPOWROTNIE UTRACONY RAJ?
}

\section{KONKWISTA MEKSYKU JAKO BOLESNY WSTRZĄS W TWÓRCZOŚCI CARMEN BOULLOSY}

ABSTRACT Irretrievably Lost Paradise? The Conquest of Mexico as a Painful Shock in the Works of Carmen Boullosa

The conquest of Mexico, which has an impact on the lives of its inhabitants today, is one of the main themes in the early works of writer Carmen Boullosa. In the novel Llanto. Novelasimposibles the author returns to the Aztec Empire to make a reinterpretation of the events of 1519-1521, while the second novel Duerme takes the reader to the days of the colonial era. Moctezuma II, who wakes up from his sleep in the second half of the twentieth century, becomes a postmodern figure. Claire, who reaches the New World on a pirate ship, becomes a witness to the exploitation of the indigenous population by the Spanish masters. Both characters are aware of the fact that the collapse of the empire means an irretrievable loss of the old world and its primary cultures.

Keywords: Conquest of Mexico, Moctezuma II, Indians

Słowa kluczowe: konkwista Meksyku, Montezuma II, Indianie 
$\mathrm{C}$ armen Boullosa to współczesna pisarka meksykańska, autorka powieści, tomików poezji, dramatów, esejów i scenariuszy filmowych. Jest laureatką prestiżowych konkursów oraz zdobywczynią wielu literackich nagród (m.in. Premio Xavier Villaurrutia oraz Premio de Novela Café Gijón). Jako wykładowca uniwersytecki przybliża swoim słuchaczom zagadnienia związane z literaturą latynoamerykańską ${ }^{1}$.

W jej dziełach głównym tematem jest fascynująca, barwna przeszłość Meksyku. Czytelnik jej utworów przenosi się do czasów imperium Azteków w powieści Llanto. Novelas imposibles (Ptacz. Powieści niemożliwe, Meksyk 1992). Wyrusza w podróż przez stulecia i trafia do Meksyku epoki kolonialnej, zobrazowanej w dziełach: Duerme (Śpi, Madryt 1994) oraz Cielos de la Tierra (Nieba Ziemi, Meksyk 1997). W Las paredes hablan (Ściany mówią, Madryt 2010) zapoznaje się z tematem rewolucji meksykańskiej, a w utworze Texas (Teksas, Meksyk 2014) - z rzeczywistością pogranicza amerykańsko-meksykańskiego połowy XIX stulecia.

Większość powieści Boullosy traktujących o przeszłości jej ojczyzny można uznać za współczesne przykłady historiograficznych metapowieści, które w opinii Seymoura Mentona charakteryzują się: zniekształceniem historii za pomocą przemilczeń i hiperbol, fikcjonalizacją postaci historycznych, obecnością metafikcji, intertekstualności, dialogiczności oraz polifonii i parodii ${ }^{2}$. Ta ostatnia w utworze literackim zostaje uwypuklona nie tylko przy użyciu wspomnianej hiperboli, lecz także za sprawą nakładania się na siebie różnych tekstów (palimpsest) ${ }^{3}$. Jak zauważa Fernando Aínsa, autor historiograficznej metapowieści dąży do dekonstrukcji przeszłości osiągalnej poprzez wyśmianie i odrzucenie wszelkich poważnych interpretacji historii i postmodernistyczną zabawę, polegającą na przemieszaniu różnych epok i obrazów ${ }^{4}$. Odbiorca powieści Boullosy wszystkie te elementy znajdzie w jej twórczości.

\section{POSTPAMIĘĆ I TRAUMA}

Rok 1492 zmienił oblicze świata oraz sposób jego percepcji. Z chwilą przybycia Hiszpanów do Ameryki cywilizacja przez nich uosabiana zderzyła się z niebezpiecznym, ale i fascynującym światem natury, reprezentowanym przez Indian. Odkrycie Ameryki zapoczątkowało proces podboju ludów Nowego Świata - w tym wojowniczego ludu Mexica - przez Europejczyków5. Wskutek konkwisty państwa Azteków przez Hernána

C. Boullosa, Carmen Boullosa. Escritora mexicana, [online] www.carmenboullosa.net, 8 XII 2016.

2 S. Menton, La Nueva Novela Histórica en la América Latina 1979-1992, [cyt. za:] A.S. Jastrzębska, Jak przysztość uksztattowata przesztość. Metapowieść historiograficzna w Ameryce Eacińskiej, Bielsko-Biała 2013, s. 27-29.

3 L. Hutcheon, Ironia, satyra, parodia - o ironii w ujęciu pragmatycznym, [w:] Ironia, red. M. Głowiński, Gdańsk 2002, s. 168-172, Tematy Teoretycznoliterackie, 3.

4 F. Aínsa, La reescritura de la historia en la nueva narrativa latinoamericana, [cyt. za:] A.S. Jastrzębska, Jak przysztość..., s. 29-30.

5 M. Tuñon de Lara, J. Valdeón Baruque, A. Domínguez Ortiz, Historia Hiszpanii, przeł. Sz. Jędrusiak, Kraków 1997, s. 210-112, 278-281. 
Cortésa upadła intrygująca, ale i budząca przerażenie zdobywców kultura. Hiszpańscy żołnierze zwalczali pogaństwo, unicestwiając ślady barbarzyńskich wierzeń. Sprowadzeni z Europy zakonnicy zakładali misje oraz redukcje, a ich mieszkańcom przekazywali zasady wiary chrześcijańskiej. W szkołach nauczali języka hiszpańskiego ${ }^{6}$. Konkwistadorzy wykorzystywali pokonaną ludność do ciężkiej pracy w hacjendach i kopalniach ${ }^{7}$ w zamian za sprawowanie opieki nad nią (system encomiendy) ${ }^{8}$. Następował stopniowy proces mieszania się różnych ras i kultur', pogłębiały się także nierówności społeczne między ludnością indiańską i metyską a Hiszpanami i Kreolami ${ }^{10}$.

Według Leopolda Zei odkryty kontynent był przez zdobywców i ich potomków postrzegany jako pozbawiony przeszłości. Stanowił plastyczną ziemię przyszłości, pozwalającą się zawłaszczyć i ukształtować w taki sposób, by służyła realizacji projektów Europejczyka ${ }^{11}$. Pierwotny mieszkaniec Ameryki w epoce kolonialnej traktowany był zatem jako przedstawiciel rasy kulturowo niższej - niezdolnej do krzewienia i wytwarzania wiedzy opartej na pracy rozumu, a zatem słusznie deprecjonowanej i wykorzystywanej przy wykonywaniu najcięższych, najmniej opłacanych prac. Owa dyskryminacja nie miała wyłącznie charakteru rasowego, ale również płciowy.

Ideałem męskości w Latynoameryce stał się silny, władczy macho. Alfredo Mirandé wyróżnia trzy hipotetyczne źródła ideologii machismo: czasy kolonialne (upokorzenia i gwałty dokonywane przez zdobywców na Indiankach pogłębiały poczucie bezsilności natywnych mieszkańców Hispanomeryki, ale budziły też w nich agresję), patriarchalną kulturę Hiszpanów oraz patriarchalną kulturę Azteków ${ }^{12}$. Gloria Anzaldúa wysuwa tezę, iż przyczyn męskiej przewagi w społeczeństwie Meksyku należy poszukiwać w mitologii Azteków. Według niej wraz z narodzinami boga wojny jego matka, Coatlicue, straciła swoją dotychczasową pozycję. Jej negatywny wizerunek utrwalili potem Hiszpanie, którym wężowa postać bogini kojarzyła się ze źródłem grzechu. Zastąpiły ją wizerunki Dziewicy z Guadalupe oraz Malinche ${ }^{13}$. Obie są przeciwieństwem aktywnego macho, postrzegane jako istoty pasywne i uległe, przy czym pierwsza (w myśl ideolo-

T. Szyszka, Zmagania ewangelizacyjne w Ameryce Eacińskiej okresu kolonialnego, [w:] Dzieje kultury latynoamerykańskiej, red. M.F. Gawrycki, Warszawa 2009, s. 126-130.

A. Moreno Toscano, Epoka wicekrólestwa, [w:] Krótka historia Meksyku, red. A. Witkowska, przeł. S. Szczurkowa, przedm. E. Szymański, Warszawa 1986, s. 87-93, Biblioteka Problemów, 284.

$8 \quad$ M. Grad, Szkice meksykańskie, Warszawa 1979, s. 84.

$9 \quad$ K. Derwich, $W$ krainie pierzastego węża. Historia Meksyku od podboju do czasów wspótczesnych, Kraków 2014, s. 21-25, Studia Latynoamerykańskie Uniwersytetu Jagiellońskiego, 14.

10 A. Hummel, A. Wądołowska, P. Płachtański, Nierówności spoteczne w Ameryce Eacińskiej, [w:] Dzieje kultury latynoamerykańskiej..., s. 209-216.

11 L. Zea, América como conciencia, [cyt. za:] F. Kubiaczyk, Nowoczesnosś, kolonialność i tożsamość. Perspektywa latynoamerykańska, Poznań 2013, s. 21-22, Badania Interdyscyplinarne - Uniwersytet im. Adama Mickiewicza w Poznaniu, 32.

12 A. Mirandé, Hombres y Machos. Masculinity and Latino Culture, [cyt. za:] R.E. Hryciuk, Kobiecość, męskość, seksualność. Pteć kulturowa (gender) w badaniach dotyczacych Ameryki Eacińskiej, [w:] Dzieje kultury latynoamerykańskiej..., s. 281-283.

13 G. Anzaldúa, Borderlands/La Frontera: The New Mestiza, [cyt. za:] F. Kubiaczyk, Nowoczesność, kolonialnośćc..., s. 268-270. 
gii marianismo) jest figurą kobiety górującej moralnie nad mężczyzną, a druga - personifikacją zdrady, zgwałconą przez Cortésa matką narodu ${ }^{14}$. Współcześnie koncepcje machismo i marianismo ulegają dezaktualizacji za sprawą przemian, które dokonują się w społeczeństwie meksykańskim. Wraz z wejściem kobiet na rynek pracy zaczęły bowiem zmieniać się role społeczne obojga płci ${ }^{15}$.

Podbój imperium Azteków jest jednak do dziś bezprecedensowym wydarzeniem, kształtującym postpamięć zbiorową wielu pokoleń Meksykanów. Według definicji zaproponowanej przez Marianne Hirsch: Postpamięć od pamięci odróżnia pokoleniowy dystans, a od historii gtęboka osobista więz. Postpamię́ jest silna i bardzo szczególna forma pamięci wtaśnie dlatego, że jej relacja wobec przedmiotu lub źródta jest zapośredniczona nie poprzez wspomnienie, ale wyobraźnię i twórczość [...]. Postpamięć charakteryzuje doświadczenie tych, którzy dorastali wśrodowisku zdominowanym przez narracje wywodzqce się sprzed ich narodzin. Ich wtasne, spóźnione historie ulegają zniesieniu przez historie poprzedniego pokolenia uksztaltowane przez doświadczenia traumatyczne, których nie sposób ani zrozumieć, ani przetworzycíc.

Pamięć kolejnych pokoleń Meksykanów o dramatycznej przeszłości wciąż jest żywa dzięki dotyczącym jej relacjom, przekazywanym od stuleci. Boullosa reprezentuje jedno z następujących po sobie pokoleń, które w swojej twórczości powracają do wielkich wydarzeń z historii meksykańskiej ojczyzny. Wiedza pisarki na temat rzeczywistości kolonialnej nie została nabyta poprzez osobiste doświadczenie, ale poprzez pamięć utrwalaną w ciągu stuleci, często w formie ustnej lub pisemnej. Autorka dokonuje w swojej twórczości reinterpretacji wydarzeń z lat 1519-1521 oraz ich konsekwencji, a jej utwory obrazują pracę postpamięci we współczesnym Meksyku.

Postpamięć w rozumieniu Meksykanina to: rozdrapywanie dawnych ran, wspominanie doznanych krzywd oraz tęsknota za utraconym rajem. W twórczości Boullosy jest obroną dorobku materialno-duchowego prekolumbijskich ludów Ameryki. Jest też krytycznym spojrzeniem autorki na wydarzenia minionych stuleci z perspektywy intelektualistki XX w. i ich ponowoczesną, parodystyczną reinterpretacją.

\section{PONOWOCZESNA INTERPRETACJA HISTORII}

Utwór Llanto. Novelas imposibles ${ }^{17}$ charakteryzują fragmentaryczna struktura oraz obecność typowego dla historiograficznej metapowieści motywu podróży postaci literackiej w czasie. Polifonia głosów: narratora, bohaterów oraz autorów minionych epok czynią z powieści dzieło intertekstualne. Jego głównym bohaterem jest inaczej niż w tradycyjnej powieści historycznej, gdzie protagoniści są postaciami

$14 \quad$ R.E. Hryciuk, Kobiecość, meskośćc..., s. 278-279.

15 Tamże, s. 270.

16 M. Hirsch, Żałoba i postpamięć, [w:] Teoria wiedzy o przesztości na tle wspótczesnej humanistyki, red. E. Domańska, Poznań 2010, s. 254.

17 B. Boullosa, Llanto. Novelas imposibles, México 1999. 
fikcyjnymi - Montezuma II, ostatni władca Azteków. Po śmierci imperatora jego ciało zostaje pogrzebane, ale po latach spędzonych w grobie władca budzi się ze snu i trafia do współczesności. Czytelnik balansuje zatem między dwiema płaszczyznami czasowymi: XVI-wieczną i współczesną.

Większosśc wydarzeń przedstawionych w utworze Llanto. Novelas imposibles rozgrywa się już po śmierci Montezumy II. O wielkim Tlatoanim, jako postaci historycznej, wiadomo, że władał imponującym tworem politycznym, jakim było Tenochtitlán. Według legendy miasto zostało założone pośrodku rozległego jeziora przez przybyszów z Aztlán. Aztekowie podbili wszystkie doliny meksykańskie i z ludu zmuszonego płacić haracz innym plemionom stali się tym, które go pobierało ${ }^{18}$. Dziwi zatem fakt, że władca pozostał bierny w chwili hiszpańskiej inwazji. Aby zrozumieć, czym się kierował, długo nie wypowiadając otwartej wojny Hiszpanom, trzeba uświadomić sobie, że jego postawę determinowały dwa nurty religijne Indian meksykańskich tamtych czasów. Pierwszy opierał się na kulcie boga wojny Huitzilopochtliego ${ }^{19}$, drugi był dziedzictwem kultury miasta Texcoco. W opinii Miguela Leóna-Portilli pierwsza koncepcja, ukazująca Azteków jako lud wybrany przez Słońce, stanowiła religijno-etyczne uzasadnienie podboju innych plemion indiańskich oraz praktykowanego przez lud Mexica obrzędu składania ofiar z ludzkich serc na szczytach piramid ${ }^{20}$. Montezuma II, różnie oceniany przez historię, tolerował ten krwawy obyczaj, nie był jednak jego zwolennikiem. Jako człowiek wychowany w kulcie dobroczyńcy ludzkości Quetzalcoatla, myśli swe kierował ku dawnej filozofii Tolteków ${ }^{21}$. Ponadto tuż przed przybyciem Europejczyków do Nowego Świata dręczyły go wizje senne; przeczuwał, że nadchodzi kres pewnej epoki. Kiedy zwiadowcy przynieśli mu wieści o zbliżających się w szybkim tempie obcych, przesądny imperator poddał się woli bogów, starając się jak najdłużej trzymać na dystans Cortésa i jego żołnierzy ${ }^{22}$.

Boullosa na nowo odczytuje opowieść o losach imperatora, porzucając jej poważne interpretacje. Strąca potężnego człowieka z piedestału, czyniąc go dość nieporadnym i zagubionym. Paola Madrid Moctezuma dostrzega w powieści humorystyczną metafikcję, a samego Montezumę ocenia jako postać anachroniczną i postmodernistyczną zarazem $^{23}$. Wielki Tlatoani budzi się w 1989 r. z letargicznego - jak dotąd sądzono: wiecznego - snu, by przenieść się do współczesności, czyli rzeczywistości dla niego całkowicie niepojętej: nie rozpoznaje miejsc, które niegdyś stanowiły jego państwo, mówi po hiszpańsku, nie wie, czemu służą wynalazki współczesności. Na ich widok przerażenie

18 E.Ch. Baity, Ameryka przed Kolumbem, przeł. M.L. Pisarek, Warszawa 1962, s. 125-127.

19 M. León-Portilla, Dawni Meksykanie, przeł. M. Sten, Kraków 1976, s. 41-44.

20 Tamże, s. 89-94.

21 Tamże, s. 116, 142-152.

22 Tamże, s. 106.

23 P. Madrid Moctezuma, Las narraciones históricas de Carmen Boullosa: el retorno de Moctezuma, el sueño virreinal y la utopia de futuro, „Biblioteca Virtual Miguel de Cervantes”, [online] http://www.cervantesvirtual.com/obra-visor/las-narraciones-histricas-de-carmen-boullosa--el-retorno-de-moctezuma-un-sueo-virreinal-y-la-utopa-de-futuro-0/html/a79178dd-046b-4595-b94d-125defa60623_7.html, 7 VII 2015. 
itrwoga oszatamiaja go $0^{24}$. Wreszcie walczy o przetrwanie ${ }^{25}$ i szuka usprawiedliwienia swojej wtasnej historii ${ }^{26}$. Tęskni do wyidealizowanej wizji Tenochtitlán jako rozkosznego miejsca, petnego zapachów kwiatów, kolorów, muzyki ptaków, które go zamieszkują ${ }^{27}$. Jest jednak już innym człowiekiem: pozbawiony przez upływ czasu korzeni, które łączyły go z dawnym imperium, staje się bezradny niczym dziecko i płacze z bezsilności. Jego klęska jako zarządcy mocarstwa, konieczność zmierzenia się z tym, co nieuchronne - upadkiem świata, w którym czuł się bezpiecznie, nie tylko są dla niego źródłem wstydu i cierpienia; przede wszystkim sprawiają, że musi zaakceptować zasady gry narzucone mu z góry. Nie jest już panem losu swych poddanych. Nie jest już nawet panem własnego losu. Zmuszony jest również zaufać trzem kobietom, które jako pierwsze napotyka po swym przebudzeniu, świadkom tego, że czas może się złamać28. Poczucie zagrożenia i samotności spycha go do roli biernego odbiorcy nieznanej mu rzeczywistości, którą musi zaakceptować. Najważniejszym symbolicznym dowodem jego wykorzenienia staje się wyrzeczenie się własnego języka i zapożyczenie mowy zdobywców. Bohater używa języka hiszpańskiego, by komunikować się z mieszkańcami współczesnego Meksyku; by mówić o ich świecie w sposób dla nich zrozumiały.

W Duerme ${ }^{29}$ czytelnik podąża za porządkiem linearnym prezentowanych przez autorkę wydarzeń. Główna bohaterka to francuska prostytutka, Claire, która na pirackim statku ucieka do Nowego Świata. Tu ma się stać ofiarą intrygi uknutej przez hrabiego Enrique de Urquiza. Ten, naraziwszy się wicekrólowi Nowej Hiszpanii, by uniknąć śmierci na szubienicy, każe indiańskim sługom przebrać dziewczynę w swój strój i zmusza ją, by w czasie egzekucji przyjęła jego tożsamość. Na szczęście stara Indianka przychodzi dziewczynie z pomocą, dzięki czemu ta odzyskuje zdrowie. Wkrótce Claire, aby uniknąć czekających ją prześladowań, opuszcza granice miasta i zapada w sen. O parodystycznym charakterze utworu świadczy zastosowana tu hiperbola - nienaturalny sen bohaterki trwa wiele lat. Podczas gdy jej ukochany wraz z upływem czasu zmienia się w starca, śniąca Claire nie traci swojej urody ani młodości. Co więcej, fakt ten nikogo nie dziwi. Ponadto nietrudno zauważyć, że Boullosa nakłada na siebie dwie opowieści: ta traktująca o losach francuskiej prostytutki jest powieleniem baśni o Śpiącej Królewnie.

W dziełach Boullosy balansowanie między przeszłością i teraźniejszością pozwala uchwycić kontrast między pozycją mężczyzny i kobiety w społeczeństwie meksykańskim dawniej i dziś. W XVI w. Montezuma jest macho, srogim panem istnień swych poddanych, samowolnie rozporządzającym ich życiem. Czytelnik znajduje w powieści fragmenty mówiące o jednej z jego nałożnic, zobligowanej do wykarmiania własną piersią przypadkowo znalezionego szczeniaka, oraz o kobietach, które zmuszone

\footnotetext{
24 C. Boullosa, Llanto. Novelas..., s. 56.

25 P. Madrid Moctezuma, Las narraciones históricas...

26 Tamże.

27 Tamże.

28 C. Boullosa, Llanto. Novelas..., s. 45.

29 Taż, Duerme, Madrid 1994.
} 
są towarzyszyć mu w podróży do zaświatów. We współczesności Tlatoani jest zagubiony i niepewny. Pozwala się prowadzić Laurze, jednej z napotkanych dziewcząt. Ta zabiera go do domu i traktuje niczym swoją zdobycz. Jak twierdzi pisarka, Montezuma w zamian otwiera jej bramę czasu ${ }^{30}$. Laura jest kobietą wyzwoloną i aktywną seksualnie, a dawny Tlatoani bezwładnie poddaje się jej woli. Zamiana dotychczasowych ról strąca władcę z piedestału, czyni go biernym.

Zdaniem Laury Pirott-Quintero w Duerme losy Claire obrazują skomplikowaną sieć stosunków między pokonanymi i zwycięzcami ${ }^{31}$. Czytelnik ma wrażenie, że męski strój, który kobieta przyodziewa w określonych sytuacjach, wpływa na jej postawę wobec otaczających ją mężczyzn. Nosząc go, jest aktywna i dzielnie broni swej czci, pokonując hiszpańskiego żołnierza. W stroju indiańskim, kobiecym, jest bezsilna i zostaje przez Hiszpana pohańbiona. Według Rosany Blanco-Cano owa nieśmiertelna dziewczyna, w męskim ubraniu zdolna do buntu i obrony samej siebie, jest symbolem utajonej sity politycznej, gotowej obudzić sięprzy pierwszej sposobności ${ }^{32}$. W powieści zatem nie brak nadziei na zrzucenie oków niewoli. Nie jest zatem prawdą, że przedstawiciele rasy i/lub płci zdominowanej przez konkwistadorów bezwładnie poddają się woli najeźdźcy. Tak naprawdę kipią z wściekłości i marzą o buncie wobec ciemiężcy.

\section{W OBRONIE KULTUR PREKOLUMBIJSKICH}

Pisarka podejmuje istotny temat wyzysku ludności indiańskiej przez jej hiszpańskich panów. Staje po stronie uciśnionych i wypowiada się w ich imieniu. Po pierwsze, broni ich, gdy Hiszpanie próbują zrzucić odpowiedzialność za śmierć Montezumy na samych Azteków. Cortés w swoich Listach utrzymuje, że śmierć władcy jest skutkiem uderzenia go w głowę kamieniem przez jednego $\mathrm{z}$ azteckich wasali ${ }^{33}$. Tymczasem autorka podaje w wątpliwość wiarygodność hiszpańskiej wersji wydarzeń, według której to sami Aztekowie mieli przyczynić się do śmierci Montezumy: Kiedy [Hiszpanie] wydobyli trupa, aby ich [Azteków] oszukać, że stuchać będa stów imperatora, zapomnieli o muzyce, która poprzedza jego pojawienie się, o bębnach, wezwaniu, bo chociaz, jako cztowiek, byt ich bliźnim, ze względu na petniony urzad byt niczym bóg. Wszystko byto fatszywe i ciato, które ktoś podtrzymywat, aby nie upadto (wszak byto już martwe), powtarzato samo sobie stowa, które powiedziano mu w dniu koronacji ${ }^{34}$.

\footnotetext{
Tamże, s. 108.
}

31 L. Pirott-Quintero, Las metamorfosis del cuerpo en "La Milagrosa" y "Duerme" de Carmen Boullosa, College of Staten Island Cuny, [online] http://lib.ugent.be/fulltxt/RUG01/001/457//982/RUG01-001457982_2001_0001_AC.pdf, 2 VII 2015.

32 R. Blanco-Cano, Revisiones a las narraciones históricas mexicanas en „Duerme” (1994) e „Isabel” (2000) de Carmen Boullosa, [online] https://pendientedemigracion.ucm.es/info/especulo/numero40/boullosa.html, 2 VII 2015.

33 H. Cortés, Cartas de relación, Madrid 1993, s. 272.

34 C. Boullosa, Llanto. Novelas..., s. 32. Jeśli nie zaznaczono inaczej, wszędzie tłumaczenie własne autorki. W oryginale: Cuando sacaron al cadáver para engañarlos que iban a oir las palabras de su emperador, 
Po drugie, odkrywa piękno kultury indiańskiej. W obydwu powieściach autorka akcentuje to, że aby istnieć, mieszkaniec Meksyku nie może oderwać się od swych korzeni, których poszukuje w świecie natury. Akcja utworu Llanto. Novelas imposibles w $1989 \mathrm{r}$. rozgrywa w Parku Luisa Gonzagi Urbina, znanym jako Parque Hundido ${ }^{35}$. Boullosa nie przez przypadek w tym miejscu umieszcza tajemnicze mrowisko, będące swoistym tunelem czasu, przez który Montezuma dociera do współczesności. Powstały w XX w., rozległy ogród imponuje nie tylko zachwycającą roślinnością, lecz także monumentalnymi reliktami przeszłości - zgromadzono tu liczne rzeźby zaliczane do sztuki prekolumbijskiej. Najważniejszym obiektem parku jest mierzący 78 metrów kwadratowych Kwiatowy Zegar (Reloj Floral ${ }^{36}$, przypominający zwiedzającym o upływie czasu i fakcie, iż historia ludzkości rozpoczęła się w świecie natury, nie cywilizacji. W ogrodzie, w którym teraźniejszość spotyka się z tym, co minione, w utworze Boullosy unosi się wiatr pamięci, a nad ziemią krążą popioły.

Pamięć o obyczajach przodków i ich postawie afirmacji życia odgrywa w powieści $D u$ erme kluczową rolę. Wprawdzie główna bohaterka jest Europejką, ale ostatecznie jej nową ojczyzną staje się Meksyk. Stara Indianka „o ciepłych dłoniach” przekazuje jej sekret życia nieznany Hiszpanom. Leczy jej rany magiczną wodą. Ta, gdy tylko zaczyna tętnić w jej żytach, zastępuje krew. W efekcie Claire pozbawiona zostaje swego dotychczasowego atrybutu - szlachetnej, europejskiej krwi, zyskując w zamian dar wiecznego życia. Jak zauważa Madrid Moctezuma: to prehiszpańskie dziedzictwo [znane tylko Indianom] taczy sie $z$ niejasnych rozmiarów atemporalnością i fantazja $q^{37}$. Indianie nie znają zdobyczy europejskiej cywilizacji, nie rozumieją praw rządzących światem Obcego-Przybysza, kierują się intuicją i wyobrażeniami o charakterze magiczno-symbolicznym. Boullosa przypisuje im również nieprzeciętne moce, które czerpią ze świata natury. Według Madrid Moctezumy w chwili owego „chrztu” (zamiany krwi w wodę) bohaterka staje się jego częścią. Przyroda jest przeciwieństwem cywilizacji, jaką przywożą ze sobą z Europy Hiszpanie ${ }^{38}$. Francuzka traci wprawdzie dawną tożsamość, ale ostatecznie znajduje dom w sercu dawnej azteckiej metropolii. O tym, że prawdziwa egzystencja poza Meksykiem nie istnieje, przekonuje się dopiero później. Zmuszona uciekać poza granice miasta, zapada w sen, z którego obudzić się może jedynie wtedy, gdy na nowo znajdzie się w jego obrębie.

Hiszpanie w powieści Boullosy działają z pozycji zdobywców. To oni narzucają podbitym Indianom nowy porządek świata, dążąc do usunięcia przejawów kultur prekolumbijskich. Indiańskie dzieci w katolickich kościołach zmuszone są śpiewać religijne pieśni. Urquiza pozbawia swoich indiańskich służących tożsamości, wszystkich

olvidaron poner la música que antecede su aparición, los tambores, la invocación, porque anuque fuera su prójimo en cuanto al ser de hombre, en cuanto al oficio era como un dios. Todo era falso, y el cuerpo que alguien detenía para no cayera (pues si era un muerto) se repetía a si mismo las palabras que le habian sido dichas el día de su coronación.

35 A. Rodríguez, Reloj Floral del Parque Hundido. El más grande de la ciudad, „Chilango” 2012, 26 XI, [online] http://www.chilango.com/ciudad/nota/2012/11/26/el-mas-grande-de-la-ciudad, 6 I 2016. Tamże.

37 P. Madrid Moctezuma, Las narraciones históricas... 
mężczyzn nazywając „Cosme”. Owo symboliczne wykorzenienie pierwotnych mieszkańców Ameryki, odebranie im należnych praw, wpisane jest w hiszpańską misję cywilizacyjną, której uzasadnienia poszukuje się, deprecjonując dorobek materialno-duchowy kultur prekolumbijskich. W efekcie świat dzieli się na dwie części: stary świat i nowe ziemie. Światto i ciemność. Ciszę i dźwięki, biel i czerń. Wodę i ziemię. Dobro i zto. Mężczyzn i kobiety. Europejczyków i inne rasy [...]. Biatych i Indian ${ }^{39}$.

Boullosa nie unika otwartej krytyki konkwistadorów. Oczyma Claire spogląda na pozostałości azteckich świątyń oraz zrujnowane przez najeźdźcę kanały i otwarcie protestuje przeciwko niesprawiedliwym osądom prekolumbijskiej kultury. Indianie są dumni ze swych korzeni. Nawet Francuzka jest świadoma tego, że zła sława, którą Hiszpanie próbują okryć pierwotnych mieszkańców Meksyku, jest efektem propagandy służącej uzasadnieniu ich misji cywilizacyjnej. Boullosa w utworze wyraźnie sygnalizuje, że zamierza bronić dziedzictwa ginących kultur: Miasto, w którym się zatrzymatam, dzieli się na dwie części: wspaniate patace hiszpańskie, uporzadkowane, ustawione w szeregu po bokach szerokich dróg, i ukryte za nimi, nieuporządkowane chaty Indian. Sa biali gtupcy, którzy będa zdania, że ten podziat istniat od zawsze; że to nasz zwyczaj. Zanim jednak przybyli, by nas zniszczyć, nasze ulice byty perfekcyjnie uporzadkowane $e^{40}$. Pamięć o przeszłości zapisana w utworze Duerme jest zatem obroną dorobku materialno-duchowego rdzennych mieszkańców Ameryki; wspomnieniem czasów, gdy człowiek egzystował w symbiozie z otaczającym go światem natury. Autorka przypomina: o martyrologii prekolumbijskich ludów, o ich oporze wobec przymusowej hispanizacji oraz o walce Indian o należne im miejsce w społeczeństwie Nowej Hiszpanii.

\section{PODSUMOWANIE}

Konkwista Meksyku, upamiętniona na kartach dzieł Carmen Boullosy, stanowi wstrząs dla wielu pokoleń podbitych i upokorzonych przez Hiszpanów Indian. Zniszczeniu wielkiego imperium towarzyszy bowiem psychiczna destrukcja bezimiennych, ludzkich jednostek zamieszkujących jego obszar. Autorka, podejmując temat martyrologii Indian, rozdrapuje bolesną ranę w sercu swej ojczyzny. Przedstawia jednak czasy kolonialne z perspektywy współczesnej intelektualistki, dlatego jej intertekstualne dzieła mają również charakter parodystyczny. W ponowoczesny sposób reinterpretuje wydarzenia z historii Meksyku, wierząc, że: Wspomnienie przywraca pamięć. Wydobywa martwych na stońce. Czyni nas pożywieniem śmierci: pożywieniem dla powieści ${ }^{41}$.

39 C. Boullosa, Duerme..., s. 57.

40 Tamże, s. 58. W oryginale: La ciudad misma donde estoy estancada se divide en dos: los magnificos palacios de los españoles, ordenados, alineados a los lados de las amplias calzadas, y las casuchas en desorden de los indios encondidas tras ellos. Hay blancos imbéciles que opinarán que asi hemos dividido siempre, que esta es nuestra costumbre. Y no bromean, es pura estupidez. Pero cuando ellos no habian llegado a arruinarnos, nuestras calles estaban trazadas en orden perfecto.

41 Taż, Llanto. Novelas..., s. 60. W oryginale: El recuerdo desentierra. Saca los muertos al sol. Nos hace carne de muerte: carne para novela. 


\section{BIBLIOGRAFIA}

Baity E.Ch., Ameryka przed Kolumbem, przeł. M.L. Pisarek, Warszawa 1962.

Blanco-Cano R., Revisiones a las narraciones históricas mexicanas en „Duerme” (1994) eIsabel” (2000) de Carmen Boullosa, [online] https://pendientedemigracion.ucm.es/info/especulo/ numero40/boullosa.html.

Boullosa C., Carmen Boullosa. Escritora mexicana, [online] www.carmenboullosa.net.

Boullosa C., Duerme, Madrid 1994.

Boullosa C., Llanto. Novelas imposibles, México 1999.

Cortés H., Cartas de relación, Madrid 1993.

Derwich K., $W$ krainie pierzastego węża. Historia Meksyku od podboju do czasów wspótczesnych, Kraków 2014.

Domínguez Ortiz A., Tuñón de Lara M., Valdeón Baruque J., Historia Hiszpanii, przeł. S. Jędrusiak, Kraków 1997.

Grad M., Szkice meksykańskie, Warszawa 1979.

Hirsch M., Żatoba i postpamięć, [w:] Teoria wiedzy o przesztości na tle wspótczesnej humanistyki, red. E. Domańska. Poznań 2010.

Hryciuk R.E., Kobiecość, męskość, seksualność. Pteć kulturowa (gender) w badaniach dotyczacych Ameryki Łacińskiej, [w:] Dzieje kultury latynoamerykańskiej, red. M.F. Gawrycki, Warszawa 2009.

Hummel A., Wądołowska A., Płachtański P., Nierówności spoteczne w Ameryce Eacińskiej, [w:] Dzieje kultury latynoamerykańskiej, red. M.F. Gawrycki, Warszawa 2009.

Hutcheon L., Ironia, satyra, parodia - o ironii w ujęciu pragmatycznym, [w:] Ironia, red. M. Głowiński, Gdańsk 2002, Tematy Teoretycznoliterackie, 3.

Jastrzębska A.S., Jak przysztość uksztattowata przesztość. Metapowieść historiograficzna w Ameryce Eacińskiej, Bielsko-Biała 2013.

Kubiaczyk F., Nowoczesność, kolonialność i tożsamość. Perspektywa latynoamerykańska, Poznań 2013, Badania Interdyscyplinarne - Uniwersytet im. Adama Mickiewicza w Poznaniu, 32.

León-Portilla M., Dawni Meksykanie, przeł. M. Sten, Kraków 1976.

Madrid Moctezuma P., Las narracioneshistóricas de Carmen Boullosa: el retorno de Moctezuma, el sueñovirreinal y la utopia de futuro, „Biblioteca Virtual Miguel de Cervantes”, [online] http://www.cervantesvirtual.com/obra-visor/las-narraciones-histricas-de-carmen-boullosael-retorno-de-moctezuma-un-sueo-virreinal-y-la-utopa-de-futuro-0/html/a79178dd-046b-4595-b94d-125defa60623_7.html.

Mignolo W., Posoccidentalismo. Las epistemologías fronterizas y el dilema de los estudios (latinoamericanos) de área, „Revista Iberoamericana” 2002, Vol. 68, nr 200, s. 847-864, [online] http://revista-iberoamericana.pitt.edu/ojs/index.php/Iberoamericana/article/viewFile/5978/6119.

Moreno Toscano A., Epoka wicekrólestwa, [w:] Krótka historia Meksyku, red. A. Witkowska, przeł. S. Szczurkowa, przedm. E. Szymański, Warszawa 1986, Biblioteka Problemów, 284.

Pirott-Quintero L., Las metamorfosis del cuerpo en "La Milagrosa” y "Duerme” de Carmen Boullosa, College of Staten Island Cuny, [online] http://lib.ugent.be/fulltxt/RUG01/001/ 457/982/RUG01-001457982_2011_0001_AC.pdf. 
Reid A., La re-escritura de la conquista de Mexico en "Llanto, novelas imposibles” de Carmen Boullosa, 2003, [online] https://pendientedemigracion.ucm.es/info/especulo/numero24/boullosa.html.

Rodríguez A., Reloj Floral del Parque Hundido. El más grande de la ciudad, „Chilango” 2012, $26 \mathrm{XI}$, [online] http://www.chilango.com/ciudad/nota/2012/11/26/el-mas-grande-de-la-ciudad.

Szyszka T., Zmagania ewangelizacyjne w Ameryce Eacińskiej okresu kolonialnego, [w:] Dzieje kultury latynoamerykańskiej, red. M.F. Gawrycki, Warszawa 2009.

Anna GRYGLASZEWSKA, absolwentka filologii polskiej i hiszpańskiej Uniwersytetu Śląskiego, doktorantka i pracownik Instytutu Języków Romańskich i Translatoryki UŚ. Jej obszar badawczy stanowią: proza Carmen Boullosy, kultura i historia Meksyku. 